\title{
KSIĄŻKA I BIBLIOTEKA W ŻYCIU ŚREDNIOWIECZNYCH I STAROPOLSKICH KONWENTÓW DOMINIKAŃSKICH NA PRZY- KLADZIE KLASZTORÓW ŚRODKOWOPOLSKICH W ŚWIETLE INWENTARZY BIBLIOTECZNYCH
}

Głównym celem Zakonu Braci Kaznodziejów (Ordo Fratrum Praedicatorum) było i jest głoszenie Słowa Bożego czyli kaznodziejstwo ${ }^{1}$. Służyć temu miały specjalne studia dominikańskie, dające wykształcenie teologiczne oraz filozoficzne. W każdym klasztorze, już od momentu jego powstania, funkcjonowała szkoła konwentualna, a w wybranych konwentach studia partykularne, później materialne, a także szkoły wyższe istniejące w każdej prowincji². Według Ireny Szostek, „szkoła - każda - aby mogła pełnić funkcje dydaktyczno-wychowawcze, musi posiadać bibliotekę jako bazę naukową i warsztat pracy”3. Zgadza się z nią Krystyna Zawadzka, która twierdzi, że ,z kształceniem zakonników, a także z pełnieniem przez nich obowiązków kapłańskich (kazania, spowiadanie, odprawianie mszy) wiązały się nierozłącznie książki”" . Kapituła generalna rzymska w 1569 r. nakazała wręcz, aby każdy klasztor miał swoją bibliotekę ${ }^{5}$. Bibliotek klasztornych było tyle ile było klasztorów ${ }^{6}$.

* Tomasz Stolarczyk - dr historii, bibliotekarz w Bibliotece Uniwersytetu Łódzkiego.

${ }^{1}$ F.D. Boespflug, Życie zakonne Braci kaznodziejów, w: Dominikanie. Szkice z dziejów zakonu, red. M.A. Babraj, Poznań 1986, s. 36; J. Salij, Duchowość dominikańska, w: tamże, s. 25.

${ }^{2}$ K. Kaczmarek, Szkoły i studia polskich dominikanów w okresie średniowiecza, Poznań 2005, s. 72; K. Zawadzka, Biblioteki klasztorne dominikanów na Śląsu (1239-1810), „Acta Universitatis Wratislaviensis. Bibliothecalia Wratislaviensia", 5 (1999) s. 18.

${ }^{3}$ I. Szostek, Biblioteka dominikanów lwowskich w świetle katalogu z roku 1776, w: Studia nad historia dominikanów w Polsce 1222-1972, red. J. Kłoczowski, t. 2, Warszawa 1975, s. 410.

${ }^{4}$ Zawadzka, Biblioteki klasztorne, s. 18.

${ }^{5}$ R. Świętochowski, Biblioteka OO. Dominikanów w Krakowie, „Archiwa, Biblioteki i Muzea Kościelne" (dalej: ABMK), 33 (1976) s. 300; T. Stolarczyk, Biblioteka tęczyckiego konwentu dominikańskiego i jej księgozbiór w początkach XVII wieku, w: Przestrzeń informacyjna książki, red. J. Konieczna, S. Kurek-Kokocińska, H. Tadeusiewicz, Łódź 2009, s. 234.

${ }^{6}$ H.E. Wyczawski, Kościelne zbiory biblioteczne (wiek XVI-XVIII), w: Dzieje teologii katolickiej w Polsce, red. M. Rechowicz, t. II: Od odrodzenia do oświecenia, cz. 2, Lublin 1975, s. 532. 
Ich funkcjonowanie regulowało ustawodawstwo zakonne, począwszy od samej reguły i konstytucji, a skończywszy na kronikach klasztornych i rejestrach wydatków ${ }^{7}$. Najważniejsze przepisy dotyczące książek i bibliotek znajdowały się w De vita regulari Humberta de Romanis, podstawowym podręczniku życia dominikanów (XIII w.). Trzynasty rozdział, zatytułowany De officio librarii, podzielony był na 4 podrozdziały. W pierwszym, Circa armarium (armarium - miejsce przechowywania broni, którą dla dominikanina była książka), określono obowiązki bibliotekarza. Miał on dbać o stan zachowania ksiąg, które nie mogły być narażone na wilgoć i pleśń oraz musiały być zabezpieczone przed deszczem. Bibliotekarz musiał w tym celu znaleźć odpowiednie miejsce do ich przechowywania, z dostępem świeżego powietrza. Szafy z książkami musiały mieć odpowiednie oznaczenia, na przykład według fakultetów. Bibliotekarz miał także obowiązek udostępniania książek czytelnikom w określonym czasie $\mathrm{i}$ aby być zawsze w pobliżu, powinien mieć celę na terenie biblioteki, albo obok niej. Do obowiązków bibliotekarza należało także prowadzenie księgi zmarłych członków konwentu (liber mortuorum), gdzie zapisywano imię i rok śmierci zakonnika. Drugi podrozdział, Circa libros, mówił o konieczności spisania wszystkich książek. Ich spis miał być przekazywany przez bibliotekarza swojemu następcy. $\mathrm{Na}$ każdej książce musiał być umieszczony napis, kto jest aktualnym jej właścicielem. Do obowiązków bibliotekarza należeć miało także gromadzenie nowych zbiorów, ich selekcja. Dublety i książki mało czytane powinny zostać sprzedane, a za uzyskane pieniądze należało kupić bardziej przydatne dzieła. Co roku lub co dwa lata, należało przeprowadzać w bibliotece skontrum, a uszkodzone książki oddać do konserwacji. Każdą zaginioną pozycję zalecano obowiązkowo odszukać. W trzecim podrozdziale, Circa usum librorum, omówiono sposoby przechowywania książek w bibliotece i kryteria, według których ustawiano na pulpitach najczęściej czytane: Biblię z glosami w całości lub jej części, Biblię bez glos, Sumy, O niedoskonatościach $i$ cnotach, $O$ watpliwościach, konkordacje, interpretacje, dekrety, $O$ rozróżnieniach moralnych, kazania różne o świętach i niedzielach przez cały rok, historie, sentencje, kroniki, pasje, legendy o świętych, Historię kościelna. Biblioteka miała być otwierana o stałych porach. Wypożyczać poza bibliotekę można było tylko za zgodą magistra studentów, a każde wypożyczenie musiało być odnotowane. Zapis anulowano przy zwrocie. Na książkach nie wolno było robić notatek, niszczyć ich, źle się z nimi obchodzić i wypożyczać dalej. Tym, którzy nie zastosowaliby się do tych zasad, przełożony powinien udzielić nagany. Jednak gdyby dogodniej było, żeby książka przechodziła z rąk do rąk, to należało ją zanotować lub wziąć zastaw i pilnować, aby została oddana w określonym terminie. W czwartym podrozdziale, Circa annexa studio, zostały omówione pomoce dla zakonników pragnących się uczyć lub pracować w bibliotece. Powinny znajdować się tam inkaust, pióra, kreda, ołówki, linijki, nożyki do ostrzenia piór i tym podobne. Pergamin otrzymać mogli ci bracia, którzy potrzebowali go do notowania wykładów, dysput i tym podobne ${ }^{8}$. Zdaniem I. Szostek ,przepisy biblioteczne

\footnotetext{
${ }^{7}$ Szostek, Biblioteka dominikanów lwowskich, s. 412, 414.

${ }^{8}$ Incipiunt instructiones Magistri Humberti De officiis ordinis, w: B. Humberti de Romanis quinti Praedicatorum Magistri Generalis Opera De vita regulari, ed. J.J. Berthier, vol. II, Casali 1956,
} 
robią wrażenie dobrze osadzonych w konkrecie, przemyślanych, wyraźnie opartych na doświadczeniu. Regulamin udostępniania idzie jak najbardziej na rękę czytelnikom, starając się równocześnie nie dopuścić do niszczenia i rozproszenia zbiorów. Bez żadnych niemal zmian, można by go i dzisiaj wywiesić w bibliotekach"'.

Przedstawiony wyżej schemat klasyfikacyjny dzieł znajdujących się w bibliotekach konwentualnych zyskał w 1573 r. dodatkową podbudowę teoretyczną. Wówczas to jezuita Antonio Possewino opublikował swoją książkę Bibliotheca selecta de ratione studiorum, w której przedstawił podział zasobów bibliotecznych w klasztorach. W myśl jego sugestii najbogatsze zbiory miały zostać skupione w następujących działach: Biblia, patrystyka, prawo kanoniczne, filozofia, medycyna, prawo, historia z geografią, poezja, wymowa, encyklopedie, słowniki, kalendarze i varia. $Z$ biegiem czasu działy te ulegały dalszym podziałom, zwłaszcza filozofia, do której zaliczano metafizykę, dialektykę oraz nauki matematyczne i przyrodnicze ${ }^{10}$

Żadnemu z braci, niezależnie od piastowanej godności, nie wolno było zabierać książek ze wspólnej biblioteki. Tego, kto bez zezwolenia wypożyczył lub w inny sposób wyciągnął książkę z biblioteki, należało skłonić do oddania i pozbawić prawa korzystania z księgozbioru. Opornego zakonnika należało przymusić do zwrotu karą karceru, a nawet ekskomuniki. Zezwolenia na wypożyczenia udzielał przeor po naradzie z ojcami ${ }^{11}$. Jakub z Korzkwi, biskup płocki, wydał szczegółowe przepisy dotyczące wypożyczania książek do domu; wymagano nawet przysięgi od wypożyczających i odpowiednich gwarancji dotyczących zwrotu książek ${ }^{12}$.

W 1308 r. na kapitule generalnej w Padwie postanowiono, że nie wolno sprzedawać ani w całości, ani w częściach, zastawiać, nikomu darowywać, ani scedowywać książek, które w jakikolwiek sposób trafiły do klasztoru. W szczególności nie wolno było sprzedawać ksiąg teologicznych osobom spoza zakonu bez specjalnej zgody prowincjała. Wszystkie książki należało przekazać do biblioteki konwentu. Jeśli jednak klasztor posiadał duplikaty jakiś ksiąg lub też pewne książki, które zdaniem przełożonych danej wspólnoty, lektorów i bibliotekarzy były mniej przydatne dla braci, to można było je sprzedać (ale tylko przeor lub jego zastępca) lub zamienić. Zezwolono również na dożywotnie wypożyczenie książek, tym zakonnikom, na ich specjalne prośby, którzy ich bardzo potrzebowali. Kapituła bolońska z 1315 r. podjęła decyzję, że nie wolno sprzedawać ani wypożyczać dzieł św. Tomasza z Akwinu ze względu na ich szczególną wartość w edukacji dominikańskiej. Postanowiono wówczas także, że we wszystkich klaszto-

s. 263-266; Szostek, Biblioteka dominikanów lwowskich, s. 410, 412-413; Stolarczyk, Biblioteka tęczyckiego konwentu dominikańskiego, s. 234-235.

${ }^{9}$ Szostek, Biblioteka dominikanów lwowskich, s. 413-414.

${ }^{10}$ B. Bieńkowska, Staropolski świat książek, Wrocław 1976, s. 147-148, 202; Z. Łuczak, Dzieje bibliotek w Sieradzu od powstania miasta do końca XX wieku, Sieradz 2007, s. 35-36.

${ }^{11}$ Szostek, Biblioteka dominikanów lwowskich, s. 412.

12 M.T. Zahajkiewicz, Zarys dziejów i znaczenie bibliotek kościelnych, ABMK, 56 (1988) s. 135 . 
rach, gdzie znajdują się Studia Generalne oraz przebywają magistrzy teologii muszą znajdować się pisma teologiczne Akwinaty. Na kapitule generalnej w Barcelonie z 1323 r. zdecydowano, że przełożeni konwentów nie mogą sprzedawać, zastawiać, zamieniać ani wypożyczać komukolwiek książek z biblioteki klasztornej. W przeciwnym razie będą musieli zwrócić wartość tych ksiąg do biblioteki ${ }^{13}$.

W prowincji polskiej, oprócz wyżej wymienionych przepisów, obowiązywały dodatkowe zasady. Zakonnik mógł dziedziczyć, za zgodą prowincjała, ksiązki po innym zakonniku. Nie mogły one jednak pochodzić od tegoż prowincjała lub z jakiegoś klasztoru czyli musiały być własnością zapisującego.

W przypadku śmierci któregoś z tych dwóch braci, ten który przeżył stawał się posiadaczem książek, ale pod warunkiem, że konwent, w którym przebywał ostatnio zmarły, będzie miał swobodny dostęp do nich. Jeżeli jednak obaj już umrą to książki będą wówczas należeć do klasztoru, w którym przebywał pierwszy ze zmarłych. Dominikanin mógł zapisać swój księgozbiór również swojemu bratu lub bratankowi, a gdy któryś z nich zmarł to wówczas książki wracały do zakonnika. Natomiast jeżeli zmarłby młody profes, to nikt nie mógł odziedziczyć książek, które ten miał po swoich rodzicach lub przyjaciołach ${ }^{14}$.

Książki w bibliotekach konwentualnych pochodziły z darów i zapisów osób spoza zakonu, spadków po zmarłych zakonnikach oraz z zakupów. Bracia, wracający ze studiów zagranicznych, musieli przywozić ze sobą „nowości” teologiczne. Zalecano również zbieranie od nowicjuszy posiadanych przez nich książek w celu włączenia ich do biblioteki konwentu.

W ciągu roku każdy klasztor zobowiązany był wydawać na zakup książek równowartość ubrania zakonników. Należało kupować dzieła autorów „poważnych", współczesnych, przede wszystkim pisarzy dominikańskich, ale obok nich także starożytnych ${ }^{15}$.

Analizując księgozbiory dominikańskie znajdujące się w bibliotekach klasztornych w Gidlach, Łęczycy, Łowiczu, Piotrkowie Trybunalskim i Sieradzu (położonych na terytorium przedrozbiorowych archidiakonatów łęczyckiego, łowickiego i uniejowskiego ${ }^{16}$ ), na podstawie ośmiu siedemnastowiecznych inwentarzy (po dwóch z każdego konwentu oprócz gidelskiego) i jednego dwudziestowiecznego, można stwierdzić, że niemal każda książka związana była z konkretną dziedziną życia codziennego Braci Kaznodziejów: nauką i nauczaniem, kaznodziejstwem, odprawianiem mszy, udzielaniem sakramentów, postem i modlitwą, kon-

${ }^{13}$ Acta capitulorum generalium ordinis Praedicatorum, wyd. B. M. Reichert, vol. II: Ab anno 1340 usque ad annum 1378, Romae 1899 (Monumenta ordinis Fratrum Praedicatorum historica, t. IV), s. 34-35, 83, 146.

${ }^{14}$ Zbiór formut zakonu dominikańskiego prowincji polskiej z lat 1338-1411, wyd. J. Fijałek, Kraków 1938, nr 300, 318, 341, 342, s. 372, 380, 387.

${ }^{15}$ Szostek, Biblioteka dominikanów lwowskich, s. 412, 414; J.A. Spież, Dominikanie w kulturze polskiego średniowiecza, „Znak”, 1973, nr 223, s. 104; J.A. Kosiński, Biblioteka konwentu dominikanów w Sieradzu na przełomie XVI i XVII w., w: Studia nad historią dominikanów w Polsce 12221972, red. J. Kłoczowski, t. II, Warszawa 1975, s. 393.

16 S. Litak, Atlas Kościoła łacińskiego w Rzeczypospolitej Obojga Narodów w XVIII wieku, Lublin 2006, s. 231, 232, 233, 235, 237. 
templacją i rozważaniem Pisma Świętego i pism ojców oraz doktorów Kościołów, a także zwalczaniem herezji ${ }^{17}$.

Zajmijmy się na początek wyżej wspomnianym szkolnictwem dominikańskim, z wyjątkiem Studium Generale istniejącego w Krakowie, który w swoim zasadniczym zrębie ukształtowało się w ciągu pierwszych kilkudziesięciu lat istnienia zakonu ${ }^{18}$. Szkoły konwentualne czyli klasztorne dzielono na nowicjat, studium grammaticae (do połowy XIV w.), i studium conventuale theologiae. Nowicjat do końca drugiej dekady XVII w. istniał w każdym klasztorze polskiej prowincji. Krzysztof Kaczmarek uważa, że był to właściwy początek edukacji zakonnej przyszłego profesa ${ }^{19}$. Nowicjat u Braci Kaznodziejów trwał rok. Jego forma zależała od tego, czy nowicjusz miał zostać tylko konwersem czyli bratem - laikiem czy też kapłanem. Tylko klerycy mieli możliwość dalszego kształcenia się. Po rozpoczęciu nowicjatu kandydat przechodził pod opiekę mistrza nowicjuszy, który opiekował się zakonną młodzieżą. Nowicjusze byli oddzieleni od regularnego konwentu i bez uzasadnionej przyczyny nie wolno było im opuszczać klasztoru; mieli również zakaz obejmowania jakichkolwiek funkcji w jego obrębie. Bez zgody odpowiedniego prowincjała lub przeora zakazane było także składanie ślu-

${ }^{17}$ Archiwum Polskiej Prowincji Dominikańskiej w Krakowie (dalej: APPDK). Copiarium privilegiorum et aliorum documentorum Conventus Lovicensis ab Anno 1600-1644 (dalej: CPDCLv), s. 26-31, 39-41; APPDK. Kopiarz dokumentów dotyczących klasztoru OO. Dominikanów w Piotrkowie 1471-1610 (dalej: KKDPt); APPDK. Copiarium privilegiorum Summorum Pontificum, regum, actum iudicalium et aliorum documentorum conventus Siradiensis Ordinis Praedicatorum spectantia 1377-1692 (dalej: CPCS), s. 173-189, 223-229; APPDK. Katalog książek biblioteki klasztoru OO. Dominikanów w Gidlach (dalej: KDG); Copiarium privilegiorum et aliorum documentorum Conventus Lanciciensis Ordinis Praedicatorum 1387-1616 - Kopiariusz przywilejów i innych dokumentów konwentu łęczyckiego Zakonu Kaznodziejów 1387-1616, oprac. T. Stolarczyk, wsp. D. Gwis (dalej: CPDCL), Łęczyca 2009, s. 69-73, 78-80; J.A. Kosiński, Biblioteka konwentu dominikanów w Sieradzu, s. 394; Z. Łuczak, Dzieje bibliotek w Sieradzu od powstania miasta do końca XX wieku, Sieradz 2007, s. 34; Stolarczyk, Biblioteka tęczyckiego konwentu dominikańskiego, s. 236.

${ }^{18}$ Kaczmarek, Szkoły i studia polskich dominikanów, s. 55; T. Stolarczyk, Szkoły dominikańskie w Łęczycy w XIII-XVI wieku, w: Ludzie i książki. Studia i szkice bibliologiczno-biograficzne. Księga pamiątkowa dedykowana Profesor Hannie Tadeusiewicz, red. E. Andrysiak, Łódź 2011, s. 413.

${ }^{19}$ Kaczmarek, Szkoły i studia polskich dominikanów, s. 56, 57; J. Kłoczowski, Kształcenie w polskiej prowincji dominikańskiej w poczatkach XVI w., „Zapiski Historyczne” (dalej: ZH), 34 (1969) z. 3, s. 115; tenże, Studia w polskiej prowincji dominikańskiej za prowincjalatu Jakuba z Bydgoszczy (1447-1478), w: Europa - Stowiańszczyzna - Polska. Studia ku uczczeniu Profesora Kazimierza Tymienieckiego, Poznań 1970, s. 464; tenże, Polska prowincja dominikańska w średniowieczu i Rzeczypospolitej Obojga (Wielu) Narodów. Studia nad historia dominikanów w Polsce, t. V, Warszawa 2008, s. 285; Stolarczyk, Szkoły dominikańskie w Łęczycy, s. 413; Kaczmarek, Szkoły i studia polskich dominikanów, s. 58-59; J. Kłoczowski, Dominikanie polscy na Ślasku w XIII-XIV wieku, Lublin 1956, s. 124, 125; tenże, Jak badać historię dominikanów w Polsce przedrozbiorowej? Trochę uwag $i$ obserwacji co do znaczenia i programu badań oraz ich miejsca $w$ historiografii polskiej, w: Dzieje dominikanów w Polsce XIII-XVIII wiek. Historiografia $i$ warsztat badawczy historyka, Lublin 2006, s. 15; w okresie średniowiecza w praktyce przyjmowano czasami nawet dziewięcio - i dziesięcioletnich chłopców (J. Kłoczowski, Dominikanie polscy, s. 125); w XVI w. do polskich klasztorów dominikańskich zgłaszali się 20-25 letni mężczyźni (Kaczmarek, Szkoły i studia polskich dominikanów, s. 105; Stolarczyk, Szkoły dominikańskie w Łęczycy, s. 414-415). 
bów poza klasztorem, do którego nowicjatu kandydat wstąpił ${ }^{20}$. W nowicjacie nowicjusze uczyli się zasad życia we wspólnocie zakonnej, zapoznawali się z tekstem reguły i konstytucjami, uczyli podstawowych modlitw, śpiewania psalmów, liturgii szacunku dla przełożonych i klasztornej własności, a zwłaszcza ksiąg. Od XIV w. w nowicjacie uczono także podstaw gramatyki łacińskiej ${ }^{21}$.

Klasztorne szkoły gramatyki istniały do połowy XIV w., kiedy to utworzono takie studia na poziomie partykularnym. Nauka w tych szkołach trwała 2 lata (pomiędzy 1325 a 1347 r. 3 lata). W zajęciach musieli brać udział ci zakonnicy (głównie młodzi), którzy byli niedostatecznie przygotowani do studiów teologicznych, zwłaszcza w dziedzinie znajomości języka łacińskiego, potrzebnego do liturgii i studiowania teologii ${ }^{22}$. „Według prawa kanonicznego, studium grammaticae należało do najbardziej podstawowych warunków otrzymania święceń kapłańskich"23. Z uczęszczania do szkoły gramatyki były zwolnione te osoby, które stosowną wiedzę (po kursie logiki) zdobyły jeszcze przed wstąpieniem do zako$\mathrm{nu}^{24}$. Studia gramatyczne miały zapewnić młodym dominikanom dobrą znajomość łaciny w mowie i piśmie (była to kontynuacja nauki zaczętej już w nowicjacie) oraz wpoić im zasady officium divinum, nauczyć śpiewać, utrwalić znajomość konstytucji zakonnych, a także poprzez odpowiednią lekturę formować ich życie religijne ${ }^{25}$.

Studium theologiae (Szkoła teologii) funkcjonowało w każdym klasztorze od momentu jego powstania, gdyż było podstawą szkolnictwa dominikańskiego. Z chwilą utworzenia partykularnych studiów teologicznych (1288 r.) pozostała mu funkcja utrwalania wiedzy z teologii. Uczęszczać do tej szkoły musieli przez cały czas wszyscy obecni w klasztorze bracia (tylko ci, którzy złożyli już śluby zakonne) niezależnie od długości ich zakonnego stażu, pełnionej funkcji

${ }^{20}$ Kaczmarek, Szkoty i studia polskich dominikanów, s. 63; rola konwersów w zgromadzeniu była w praktyce dość ograniczona. Konstytucje zakonne regulowały w oddzielnych przepisach ich modlitwy, sposób ubrania i formy życia klasztornego. Znajdowali się pod opieką mistrza konwersów (magister conversorum). Konwersi wykonywali zwykłe czynności związane z codziennym funkcjonowaniem konwentu. (R. Kubicki, Środowisko dominikanów kontraty pruskiej od XIII do połowy XVI wieku, Gdańsk 2007, s. 64; Stolarczyk, Szkoły dominikańskie w Łęczycy, s. 415).

${ }^{21}$ K. Kaczmarek, Szkoły i studia polskich dominikanów, s. 64; Stolarczyk, Szkoły dominikańskie w Łęczycy, s. 415-416.

${ }^{22}$ P. Kielar, Studia nad kultura szkolna i intelektualna dominikanów prowincji polskiej $w$ średniowieczu, w: Studia nad historia dominikanów w Polsce 1222-1972, red. J. Kłoczowski, t. 1, Warszawa 1975, s. 271-272.

${ }^{23}$ Tenże, Organizacja szkolnictwa dominikańskiego w Polsce w XIV w., ,Sprawozdania z Czynności Wydawniczej i Posiedzeń Towarzystwa Naukowego KUL" (dalej: SCWPTNKUL), 17 (1968) s. 160.

${ }^{24}$ Kaczmarek, Szkoły i studia polskich dominikanów, s. 69, 118; Stolarczyk, Szkoły dominikańskie w Łęczycy, s. 417-418.

${ }^{25}$ Kaczmarek, Szkoły i studia polskich dominikanów, s. 67, 70; P. Kielar, Organizacja szkolnictwa dominikańskiego w XIV w., „Studia Philosophiae Christianae”, 5 (1969) s. 306; J. Kłoczowski, Zakon dominikański i początki wyższego szkolnictwa na ziemiach polskich, w: Dominikanie - Gdańsk - Polska - Europa, red. D.A. Dekański, A. Gołembnik, M. Grubka, Gdańsk-Pelplin 2003, s. 72. 
i duszpasterskiego doświadczenia. Była to szkoła permanentnego kształcenia teologicznego ${ }^{26}$. „Szkoły te odgrywały ogromną rolę w religijnym oraz umysłowym formowaniu zakonników i dawały im odpowiednią podbudowę teologiczną, niezbędną w posłudze duszpasterskiej, misjach, polemikach z heretykami i działalności inkwizycyjnej. [...] niektóre dominikańskie konwentualne szkoły teologii [...] nabrały charakteru studiów publicznych i otworzyły swe drzwi dla kleru diecezjalnego"27. Nauczanie w szkołach konwentualnych miało zatem charakter praktyczny - przygotowywało do głoszenia kazań i spełniania czynności duszpasterskich $^{28}$. W konwentualnym studium teologicznym wykładano Biblię z glossami, Sentencje Piotra Lombarda, Historie scholastyki Piotra Comestora, a także wybrane traktaty św. Tomasza z Akwinu (od XIV w.) ${ }^{29}$. Duże zastosowanie miały także podręczniki dla spowiedników ${ }^{30}$.

Do szkół partykularnych, a od końca XVI w. materialnych uczęszczali, bracia, którzy wyróżniali się zdolnościami, mieli odpowiedni staż życia w zakonie, posiadali dobra znajomość łaciny, konstytucji zakonnych, liturgii i śpiewu kościelnego. Były przeznaczone tylko i wyłącznie dla dominikanów. Studia partykularne przygotowywały swoich słuchaczy do nauki i wykładów w zakonnych studiach generalnych ${ }^{31}$. „Studium partykularne miało w zasadzie program podobny do generalnego i obejmowało wieloletni cykl zajęć, od znajomości łaciny, czyli gramatyki, poprzez filozofię do teologii; od generalnego różniło się zapewne tylko poziomem, brakiem specjalizacji i bardziej powierzchownym realizowaniem tego scholastycznego programu [...]"32. W XIV i XV w. dominikanie łączyli w jednym klasztorze nauczanie różnych dyscyplin ${ }^{33}$. Studia partykularne dzieliły się na studia artium/logice, w których wykładano Analityki pierwsze (Analitica priora), Analityki wtóre (Analitica posteriora), Kategorie (Categoriae), Topiki (Topi-

${ }^{26}$ Kaczmarek, Szkoty i studia polskich dominikanów, s. 72; Kłoczowski, Polska prowincja dominikańska $w$ wiekach średnich, SCWPTNKUL, s. 50; tenże, Dominikanie polscy, s. 215; tenże, Zakon dominikański, s. 69; tenże, Polska prowincja dominikańska w średniowieczu, s. 22-23, Kielar, Studia nad kultura szkolna, s. 464; tenże, Organizacja szkolnictwa dominikańskiego w XIV w., s. 305-306; tenże, Organizacja szkolnictwa dominikańskiego w Polsce, s. 159-160, 161; Spież, Dominikanie w kulturze, s. 96.

${ }^{27}$ Kaczmarek, Szkoty i studia polskich dominikanów, s. 72.

${ }^{28}$ Kielar, Studia nad kulturą szkolna, s. 275; Stolarczyk, Szkoty dominikańskie w Łęczycy, s. $418-420$.

${ }^{29}$ Kielar, Studia nad kultura szkolna, s. 275; Kaczmarek, Szkoty i studia polskich dominikanów, s. $84-85$.

${ }^{30}$ Kielar, Studia nad kultura szkolna, s. 275.

${ }^{31}$ Kaczmarek, Szkoty i studia polskich dominikanów, s. 168; J. Flaga, Formacja i kształcenie duchowieństwa zakonnego w Rzeczypospolitej w XVII i XVIII wieku, Lublin 1998, s. 59; Świętochowski, Biblioteka OO. Dominikanów w Krakowie, s. 213; M. Łobozek, Przygotowanie do kaptaństwa $w$ zakonach polskich $w$ XVII $i$ XVII $w$., w: Kultura intelektualna $w$ zakonach polskich w XVII i XVIII wieku. Materiały z sesji naukowej Katedry Historii Zakonów zorganizowanej 27 października 2005 roku, red. M. Łobozek, Kraków 2006, s. 64-65; Stolarczyk, Szkoły dominikańskie $w$ Łęczycy, s. 420.

${ }^{32}$ Kłoczowski, Ksztatcenie, s. 120.

${ }^{33}$ Kaczmarek, Szkoty i studia polskich dominikanów, s. 238. 
ca) i Peri hermenais Arystotelesa, Isagoge (Isagoga) Porfiriusza, De sophisticis elenchis i Liber de sex principiis Gilberta de la Porče oraz Summulae logicales (Traktat) Piotra Hiszpana ${ }^{34}$, Studium naturarum-naturalium/philosophiae (Szkoła filozofii), w którym wykładano filozofię naturalną i moralną (etykę), opierając się przede wszystkim na dziełach Arystotelesa i komentarzach do nich oraz wybrane pisma św. Tomasza ${ }^{35}$ oraz Szkoły teologii, trwające 3 lata, a wykładano w nich przez 2 lata Biblie, a przez rok Sentencje Piotra Lombarda ${ }^{36}$.

Do form nauczania w szkołach dominikańskich należały: lectio - wykład prowadzony dwukrotnie w ciągu dnia przez odpowiedniego lektora; disputatio - dysputa od 1619 r. odbywana codziennie pod kierunkiem lektora głównego (principalis) i przy udziale wszystkich lektorów i studentów, (brali w nich udział także goście spoza klasztoru); examen - przepytywanie z materiału przerobionego na lekcji, urządzane przez odpowiednich lektorów raz lub kilka razy w tygodniu; repetitio - powtórki przerobionego materiału i wyjaśnienia odbywane pod kierunkiem magistra studentów lub lektora i collatio - konferencja religijna na podstawie przerobionego materiału w każdy piątek ${ }^{37}$.

Do najważniejszych zadań Braci Kaznodziejów należało kaznodziejstwo. W ciągu roku w ich kościołach wygłaszano od 240 do 250 kazań. Dominikanie głosili je rano i wieczorem, w niedziele i święta, w każdy dzień wielkiego postu, w Wigilię Bożego Narodzenia i Zesłania Ducha Świętego, w dni krzyżowe i soboty suchych dni oraz w czasie oktawy Wielkanocy i Zesłania Ducha Świętego ${ }^{38}$. Zbiory kazań zajmowały w każdym klasztorze dominikańskim poczesne miejsce. Według wspomnianych wyżej inwentarzy najwięcej było ich w bibliotece konwentualnej w Sieradzu - ok. 100 woluminów $^{39}$. Kaznodzieje dominikańscy z Gidli, Łowicza, Łęczycy, Piotrkowa Trybunalskiego i Sieradza przygotowując homilie mogli korzystać z kazań Bernarda de Bustis, Pelbarta de Themeswar, Mikołaja z Lyry, Pseudo-Pierre'a de La Paluda, Wilhelma z Meffret, Johannesa Wilda

${ }^{34}$ Szkoty i studia polskich dominikanów, s. 178-179; J.B. Korolec, Struktura organizacyjna szkót dominikańskich, „Materiały i Studia Zakładu Historii Filozofii Starożytnej i Średniowiecznej” (dalej: MSZHFSŚ), 9 (1968) s. 14.

${ }^{35}$ Kaczmarek, Szkoły i studia polskich dominikanów, s. 190-192; Kielar, Organizacja szkolnictwa dominikańskiego w Polsce, s. 163; tenże, Organizacja szkolnictwa dominikańskiego w XIVw., s. 308, 309; Korolec, Struktura organizacyjna szkót dominikańskich, s. 7, 14; Kłoczowski, Zakon dominikanski, s. 72.

${ }^{36}$ P. Kielar, Organizacja szkolnictwa dominikańskiego w Polsce, s. 161; tenże, Organizacja szkolnictwa dominikańskiego w XIV w., s. 307; tenże, Studia, s. 277; Spież, Dominikanie w kulturze, s. 101; Korolec, Struktura organizacyjna szkót dominikańskich, s. 17, 21.

${ }^{37}$ Acta Capitulorum Provinciae Poloniae Ordinis Praedicatorum (dalej: ACPPOP), vol. II, (mps w Bibliotece Kolegium Filozoficzno-Teologicznego Dominikanów w Krakowie), s. 335-349; P. Kielar, Studia, s. 285; Spież, Dominikanie w kulturze, s. 100; Stolarczyk, Szkoły dominikańskie $w$ Łęczycy, s. 414.

${ }^{38}$ W. A. Hinnebusch, Dominikanie - krótki zarys dziejów, w: Dominikanie. Szkice z dziejów zakonu, red. M. A. Babraj, Poznań 1986, s. 123.

${ }^{39}$ APPDK. CPCS, s. 173-189, 223-229; Kosiński, Biblioteka konwentu dominikanów w Sieradzu, s. 397, 401; R. Skrzyniarz, Zbiory kazań w polskich księgozbiorach okresu średniowiecza, ABMK, (70) 1998 s. 256; Łuczak, Dzieje bibliotek w Sieradzu, s. 39-41. 
(Ferusa), Piotra Skargi, Fryderyka Nausea (Blandicampianusa), Leonarda z Utino (Udine), Osvalda de Lasco, Roberta Caracciolusa z Licio, Johanna Herolda (Discipulusa), Thomasa Trugillo, Jana de Verdena, Wincentego Ferreriusza, Juana Osorio, Jakuba de Voragine, Ludwika z Grenady zw. Granatensis, Cherubina ze Spoleto, Franciszka Polygranusa, Henryka Helmezjusza, Johannes Hoffmeistera, Jana Groppera, Jakuba Schopperusa, Jana Lanspergiusa (Landspergusa, Landsberga), Johanna Ecka (Eckiusa), Johannesa de Aquila (Aquilanusa), św. Bernarda z Clairvaux, Piotra Comestora, Walentego Poznańskiego, św. Bonawentury, Gabriela Biela, Marcina Białobrzeskiego, Johannesa Heigerlina (Fabera), Piotra Jeremiasza z Palermo (Panormitanusa), św. Bedy Czcigodnego, Georga Witzela (Wiceliusa), Stanisława Karnkowskiego, Jana biskupa Saint-Brieuc (-Treguier), Johna Bromyarda, Felippe Luzytani Dieza (Diaza), Gelles'a Dominique'a Topiariusa, Guillaume'a Pepina, Paula Wana (Wanna), Flaccusa Alcuinusa, Guilelmusa de Militona, św. Bernardyna ze Sieny, Jana Gritscha, Dionizego Wielkiego, Hugona de Prato Florydo, Mikołaja z Błonia, Kaspra z Granady, Jeana Raulina, Jana Roiarda, Sylwestra de Prierio, Thomasa Stapletona, Martina Eisengreina, Dionizego Kartuza, Ambrożego de Spiera, Antoniusa de Balocco (de Verceil), Piotra Ravenatusa (Chryzologa), Gabriela Baralety, Guillermusa Parisiensi, Wawrzyńca Suriusa, Arnaldusa Roiardi, Diego de la Vega, Pierre'a de Besse, Willera van Spoelberch, Kacpra Sancheza, św. Franciszka Salezego, Matthiasa Fabra, Abrahama Bzowskiego, Phillipe'a Bosquiera, św. Antoniego z Padwy, Jacka Liberiusza, Szymona Staropolskiego, Franciszka Rychłowskiego, Heinricha Helma, Raoula L'Ardent, Maximilianusa van der Sandt, Thomasa Reina, Adriana van Hofstade, Stanisława Zakrzewskiego, Johanna Arnolda Cholinusa, Thomasa de Sally, Juana de Carthagena ${ }^{40}$. Pomocne były także Explicationes Hymnorum (Objaśnienia do Hymnów), Commentaria super sequentias de Sanctis, Librum Psalmorum brevis explanatio pióra Marcusa Antoniusa Flaminiusa (Marcantonio Flaminio), Commentarium in psalterium, Psalterium cum Paraphrasi Rainiero (Rajnera) Sacchoni (Snoygoudanosa) ${ }^{41}$. Kaznodzieje uczyli się sami także sposobów głoszenia swoich kazań. Korzystali z podręczników retoryki starożytnych autorów takich jak: Kwintylian (Marcus Fabiusz Quintilianus): Oratoria Institutionis, Fortunat: De arte oratoria, Cyceron (Marcus Tulius Cicero): Rhetorica, De Inventione, Talona Omera (Talaeusa Audomara): Rhetorica ad Carolum Lotharginum Cardinalem, Johannesa Caesariusa Dialectica ${ }^{42}$.

Przygotowując się do odprawiania mszy św. i udzielania sakramentów dominikanie korzystali z Pupilla oculi Johna Burgh'a, De ratione et sacrificio Missae ${ }^{43}$ biskupa Andrzeja Krzyckiego, Tractatus sacerdotalis de Sacramentis Mikołaja

${ }^{40}$ APPDK. CPDCLv, 26-31, 39-41; APPDK. KKDPt; APPDK. CPCS, s. 173-189, 223-229; APPDK. KDG; Kosiński, Biblioteka konwentu dominikanów w Sieradzu, s. 397; Stolarczyk, Biblioteka tęczyckiego konwentu dominikańskiego, s. 238-239.

${ }^{41}$ APPDK. CPDCLv, 26-31, 39-41; Stolarczyk, Biblioteka tęczyckiego konwentu dominikańskiego, s. 240.

${ }^{42}$ APPDK. CPDCLv, s. 31; APPDK. KKDPt.

${ }^{43} \mathrm{~K}$. Estreicher, Bibliografia polska, cz. III: Obejmująca druki stóleci XV-XVIII w układzie abecadłowym (dalej: Estreicher, cz. 3), t. IX, Kraków 1905, s. 331. 
z Błonia ${ }^{44}$, De Septem Sacramentis i Mysterii missae expositio Fransa Titelmana, De Septem Sacramentis Hannibala Rosselli, De Eucharistia Georga Witzela, De Eucharistia Basiliusa Besaariona, De divinis Catholicae Ecclesiae officiis et mysteriis Melchiora Hittorpa, Confessio Catholicae Fidei Christiana Stanisława Hozjusza, anonimowego autora dzieło o tym samym tytule z synodu piotrkowskiego, De divinis apostolicis, atque ecclesiasticis traditionibus Martina Pereza de Ayala, oraz Carmina quaedam, Psalterium św. Brunona z Würzburga, De Sacramento Eucharistiae Hrabana Maura, De missa, ewangelia et veritate corporis et sanguinis Christi in Eucharistia Jana Fabra, Rationale divinorum officiorum Wilhelma Duranta, De sacra altaris ministerio Innocentego III, biskupa Piotra Gębickiego, brewiarzy oraz z Ordinarius ceremoniarium Fratrum Praedicatorum ${ }^{45}$.

Spowiednicy dominikańscy przygotowując się do udzielania sakramentu pokuty czytali podręczniki dla spowiedników i dzieła z teologii moralnej: Grzegorza I Wielkiego Liber moralium (Moralia) seu Expositio in Job, Anioła de Clavasio Summa angelica de casibus conscientiae, Andreasa de Escobar: Modus confitendi, Martinusa Azpilcuety Enchiridion sive mannuale confessariorum et penitentium, Thomasa Stapletona: Promptuarium morale, św. Rajmunda z Peńafort $\mathrm{Ca}$ sus coscientiae, Piotra z Soto Methodus confessionis, Antoniego Pierozzi (Antoniego de Foligno): Summa confessionalis, Marka Marulicia De bene vivendi institutione, Wilhelma Peralda Summa virtutum et vitiorum, Jana Graffa z Kapui Decisiones Aureae casuum conscientiae, Franciszka Toletusa Instructio sacerdotum ac poenitentium, Juana Azora Institutiones Morales, Grzegorza Terencjusza Confessio et Instructio Idiotae, Hermana Busembauma Medulla Theologiae Moralis, Szymona Salazara Promptuarium rerum moralium traktaty Jana Gersona ${ }^{46}$.

W klasztorach Braci Kaznodziejów pilnie studiowano Biblię i Konkordancje m.in. Antoniusa Broickwy von Königstein oraz komentarze do Pisma Świętego: $\mathrm{m}$. in. Kajetana z Tieny (Gaetano dei Conti di Tiene), Nicholasa Zegersa Tacitusa, Wojciecha Nowopolskiego (Nowopolczyka), Richarda Lutha, Jeana de Gagny, Johanna Wilda (Ferusa), Juana de Torquemada, Pseudo-Dionizego Areopagity, Guilliauda Claude'a, św. Tomasza z Akwinu, Teofilakta, Abrahama Bzowskiego, Silvestro Mazzoliniego de Prierio, Mikołaja z Liry, Korneliusza Jansena, Didacusa Stelli (Diego Estelli), Dominika Soto, Korneliusza Mussa, Jana Hofmeistera, Jana Ferusa, Pawła Palaciusa (Paolo de Palacio), św. Dionizego Wielkiego, Angelomusa z Luxeuil, Seduliusa Scota, Fryderyka Nausea, Blasiusa Viegas, Paula Sherlocka, Corneliusa Cornelissena van den Steen (Corneliusa Cornelli a Lapide) i nieznanego autora Psalmi enarrati et castigati ${ }^{47}$.

${ }^{44}$ Tractatus sacerdotalis Vnerabilis viri Mag. Ni. de plove decretorum doctoris et capelani episcopi posnaniensis ...deque diuinis officiis et eorum administrationibus wiele wydań (Estreicher, cz. 3, t. 2, Kraków 1894, s., 171-175).

${ }^{45}$ APPDK. CPDCLv, s. 31; APPDK. KKDPt; Kosiński, Biblioteka konwentu dominikanów w Sieradzu, s. 398-399; Stolarczyk, Biblioteka tęczyckiego konwentu dominikańskiego, s. 240.

${ }^{46}$ APPDK. CPDCLv, s. 27-31; APPDK. KKDPt; APPDK. KDG; Kosiński, Biblioteka konwentu dominikanów w Sieradzu, s. 396-397; Stolarczyk, Biblioteka tęczyckiego konwentu dominikańskiego, s. 238.

${ }^{47}$ APPDK. CPDCLv, s. 27-31; APPDK. KKDPt; APPDK. KDG; Kosiński, Biblioteka konwentu dominikanów w Sieradzu, s. 396; Stolarczyk, Biblioteka tęczyckiego konwentu dominikańskiego, s. 237. 
Do lektur dominikańskich należały również pisma Ojców, Doktorów i Apologetów Kościoła: św. Augustyna z Hippony, św. Tomasza z Akwinu, św. Grzegorza z Nazjanzu, św. Ambrożego, Laktancjusza, św. Cypriana, św. Izydora z Sewilli, Jana Chryzostoma Złotoustego, św. Hieronima, św. Jana Damasceńskiego, św. Euzebiusza papieża, św. Grzegorza Wielkiego, św. Atanazego, św. Bazylego Wielkiego z Cezarei, św. Cyryla Aleksandryjskiego ${ }^{48}$.

Dominikanie w zaciszu swoich klasztorów uprawiali również ascezę i kontemplowali. W ćwiczeniach duchowych pomocne były im w interesujących nas konwentach dzieła Dionizego Kartuza, Hendrika Herpa Speculum aureum decem praeceptorum, Tomasza a Kempis De Imitatione Christi, Alain'a de la Roche (Alanusa de Rupe) Psalterium Beatae Virginis Mariae, św. Bonawentury Vita Christi, Ludolfa Kartuza Meditaciones Vitae Domini nostri Jesu, Johannesa Wilda (Ferusa): Sacrosancta passionis salvatoris nostri Jesu Christi historia ex quatuor Evangelistis studiose concinata et in quatuor partes rite distincta, Humberta de Romanis, Thomasa Stapletona, Diego Estelli De contemnendis mundi vanitatibus, Ludwika z Grenady Dux peccatorum, Willema Damasz van der Linden Meditationes in psalterium i anonimowego autora Jesus in Passione, Luisa de la Puente Meditationes de praecipuis fidei nostrae mysteriis, vitae ac passionis D. N. Jesu Christi et B.V. Mariae, Antoine'a Sucqueta Via vitae aeternae, Kaspra Drużbickiego Tractatus de variis Passionem Domini nostri Jesu Christi Meditandi modis ${ }^{49}$.

Zakonnicy czytali także dzieła hagiograficzne: Wincentego z Kielczy Vita sancti Stanislai Cracoviensis episcopi (Vita maior) lub Vita sancti Stanislai episcopi Cracoviensis (Vita minor), Jakuba de Voragine: Legenda aurea Sanctorum, sive Lombardica historia, Vita sancti Stanislai et patronorum Poloniae oraz Piotra Kanizjusza Notae de Sanctis, Piotra Skargi Żywoty Świętych ${ }^{50}$, Antoniego Grodzi-

${ }^{48}$ APPDK. CPDCLv, s. 26-31, 39-40; APPDK. KKDPt; Kosiński, Biblioteka konwentu dominikanów w Sieradzu, s. 396; Stolarczyk, Biblioteka tęczyckiego konwentu dominikańskiego, s. 237.

${ }^{49}$ APPDK. CPDCLv, s. 27, 30-31; APPDK. KKDPt ; APPDK. KDG; Kosiński, Biblioteka konwentu dominikanów w Sieradzu, s. 398; Stolarczyk, Biblioteka tęczyckiego konwentu dominikańskiego, s. 240.

${ }^{50} \dot{Z} y$ woty Swiętych Starego y nowego zakonu na każdy dzień przez caly rok, wybrane z poważnych pisarzow y doktorów Kościelnych, ktorych imiona niżey sa połozone. Do ktorych przydane sa niektore duchowne Obroki y nauki przeciw kacerstwom dzisieyszym, tam gdzie sie żywot ktorego Doktora starożytnego położyt. K temu kazania krotkie na ty święta, ktore pewny dźień w Miesiacu maia. Przez Księdza Piotra Skargę Societatis Jesu, przebrane, uczynione y vv ięzyk Polski przetozone. teraz znowu przez niegoż przegladane y trzeci raz $w$ druk podane, Kraków 1592; Żywoty Swiętych Starego y nowego zakonu na każdy dzień przez caly rok, wybrane z poważnych pisarzow y doktorów Kościelnych, ktorych imiona niżey sa połozone. Do ktorych przydane sa niektore duchowne Obroki y nauki przeciw kacerstwom dzisieyszym, tam gdzie się żywot ktorego Doktora starożytnego położyt. K temu kazania krotkie na ty święta, ktore pewny dźień w Miesiącu maia. Przez X. Piotra Skargę Societatis Jesu, przebrane, uczynione y w ięzyk polski przełożone. Teraz znowu przez niegoż przegladane y czwarty raz w druk podane, Kraków 1598; Kazania O Siedmi Sakramentach Kościoła S. Katolickiego. Do ktorych sa przydane Kazania Przygodne, o rozmaitych nabożeństwach wedle czasu, ktorych iest wypisany na przodku regestr. Czynione y napisane od X. Piotra Skargi Societatis Jesu, Kraków 1600; Kazania Na Niedziele y Swięta, catego Roku X. Piotra Skargi, So- 
ckiego i Seweryna Lubomlczyka życiorysy św. Jacka Odrowąża ${ }^{51}$, Grzegorza z Tours Vita Patrum, Pedro de Ribadeneira Flos sanctorum seu Vitae et res gestae sanctorum, Bartłomieja Pawła Szotarewicza Byssus et Purpura Seu Vita et Martyrium D. Stanislai Episcopi Cracoviensis ${ }^{52}$.

Canes Domini mieli strzec czystości wiary katolickiej. Papież Grzegorz IX uczynił ich inkwizytorami, którzy musieli być doskonałymi teologami, aby mogli stawić czoło innowiercom i heretykom. Studiowali zatem dzieła z teologii spekulatywnej i dogmatycznej oraz pisma polemiczne: przede wszystkim św. Tomasza z Akwinu na czele z Summa Theologiae (Summa Theologica), Piotra Lombarda Sententiae, Ryszarda od św. Wiktora, Antonina Pierozzi de Foligno, Johanna von Tritenheim, Silvestro Prierias Mazzoliniego, Baptysty de Salis, Thomasa de VioKajetana, Juana de Torquemada, Gottschalka Hollena, Johanna Hoffmeistera, Paula Weidnera, Thomasa Palmerstona (Hybernicusa), Giovani'ego Bologni (Jana z Bolonii), Georga Witzela, Konrada Klinga, Jana Magistra, Johanna Versora, Batolomeo Fumi, Jeana Vigneri, Bartolomeusa Westhemera (Vesthemera, Westheimera), św. Rajmunda z Peńafort, Johanna Herolta (Discipulusa), Jana Berarda, Bartłomieja z Medyny, Dominika Soto, Roberta Holkota, Stanisława Hozjusza, Lawrence'a Arthura Faunta, św. Prospera Aquitanusa, Franciszka Kostera, Wilhelma van der Lindt, Thomasa Stapletona, Johanna Ecka (Johanna Maiera), Jakuba Górskiego, Walentego Poznańskiego (Wróbla), Alfonsa de Castro, Roberta Bellarmina, św. Hilarego, św. Ireneusza, Wojciecha Nowopolskiego, Marcina Białobrzeskiego, Stanisława Orzechowskiego, Jana Sakrana, Stanisława Sokołowskiego, Giovanniego Balbi di Genoa, Jakuba Wujka, Guillermusa de Valle Rouillonis (Guillaume Vorrlona), Jose Clichtove, Piotra Maurycego, Bartolomeo Fumo, św. Piotra Męczennika, Ferdynanda Januszewskiego-Ohma, Williama Reynoldsa, Wojciecha Waleriana Gutowskiego, Jeana Baptisty Goneta, Jeana Dadré oraz anonimowego autora Iudicium de censura ministrorum Tigurinorum $^{53}$.

Książka towarzyszyła dominikaninowi od momentu wstąpienia do nowicjatu

cietatis Jesu. Dwa sa przy nich Regestry. Jeden do nauk na zmocnienie Katholickiey wiary: A drugi do naprawy obyczaiow stużacy, wiele wydań (Estreicher, cz. 3, t. XVII, Kraków 1930, s. 142-145, 147, 162-163).

${ }^{51}$ O żywocie, cudach y postępku kanonizacyey Btogosławionego Jacinkta fundatora pierwszego w Polszcze: braciey zakonu kaznodzieyskiego Dominika świętego czworo ksiag, przez Oyca Antoniego Grodzickiego przeora krakowskiego Conwentu świetey Troyce tegoz zakonu wydane. Ciała świetych w pokoiu pogrzebione sa, a imie ich zywie od narodu do narodu. Madrość ich niech powiadaja ludzie, a chwałe ich niechay sławi Kościół. Kraków 20 lipca 1595 (Estreicher, cz. 3. t. t. X, Kraków 1906, s. 485-486).

${ }^{52}$ Byssus Et Purpura Seu Vita et Martyrium D. Stanislai Episcopi Cracoviensis, Historico Stylo Infertis etiam nonnulis encomiorum flosculis. Contexta a Pr: Bartholomeo Sotarevio Ordinis Sancti Pauli primi Eremitae Presbytero, typis Clari Montis Czestochoviensis (Estreicher, cz. 3, t. XIX, Kraków 1934 , s. 295; APPDK. CPDCLv, s. 30-31; APPDK. KKDPt; APPDK. KDG; Kosiński, Biblioteka konwentu dominikanów w Sieradzu, s. 398; Stolarczyk, Biblioteka tęczyckiego konwentu dominikańskiego, s. 239.

${ }^{53}$ APPDK. CPDCLv, s. 26-31, 39-41; APPDK. KKDPt; APPDK. KDG; Kosiński, Biblioteka konwentu dominikanów w Sieradzu, s. 396-398; Stolarczyk, Biblioteka tęczyckiego konwentu dominikańskiego, s. 237-239. 
aż po śmierć. Była niezbędna przy studiach i ustawicznym kształceniu się, którego wymagało ustawodawstwo zakonne, a także przy codziennych zajęciach braci: kaznodziejstwie, odprawianiu mszy, udzielaniu sakramentów, poście i modlitwie, kontemplacji i rozważaniu Pisma Świętego i pism Ojców oraz Doktorów Kościoła, a także zwalczaniu herezji.

\title{
BOOK AND LIBRARY IN LIFE OF MEDIEVAL AND OLD POLISH ST DOMINIC'S CONVENTS EXEMPLIFIED BY MONASTERIES IN CENTRAL POLAND IN VIEW OF LIBRARY COLLECTION
}

\begin{abstract}
Summary
A book accompanied a Dominican monk from the moment of joining the novitiate till his death. It was indispensable during the studies and lifelong learning that was required by the rules or laws made by the Convent, and during daily chores of months: preaching, celebrating the mass, providing the sacraments, fasting and praying, contemplating and meditating the Holy Scriptures, and writings by the Fathers and Doctors of the Church, as well as combating the heresy. One can ascertain about it through analyzing the Dominican book collections maintained in the libraries of the monasteries in Gidly, Łęczyca, Łowicz, Piotrkow Trybunalski and Sieradz, by browsing through 8 library collection sets dating back to 17 th Century and the one collection set dating back to 20th Century.

The major objective of the Order of Friars Preachers (Ordo Fratrum Praedicatorum) was and still is to disseminate the Words of God, namely preaching. The large emphasis was put on education. Special Dominican studies providing education in theology and philosophy served these purposes. After establishment of every monastery, an affiliated Conventual school was set up. In a number of convents, particularistic studies, later substantive studies as well as advanced education institutions were opened in each province. Libraries, indispensable for schools, were inseparable from schools because they actually were the scientific base and workplace. There were as many libraries as monasteries. Their operations were governed by the rules or laws made by the Convent, beginning with the very specific rules and the constitution, and ending with monastic chronicles and records of expenditure.

Within one year in Dominican Churches from 240 to 250 sermons were preached. Collections of sermons occupied a prominent place in every Dominican monastery. Given the aforementioned library collections, the largest of them was found in the conventual library in Sieradz - approximately 100 volumes. Preparing a homily, Dominican preachers from Gidla, Łowicz, Łęczyca, Piotrkow Trybunalski and Sieradz could make use of the sermons inter alia by Bernard de Bustis, Pelbart de Themeswar, Nicholas of Lyra, Pseudo-Pierre'a de La Paluda, Wilhelm Meffreth, Johannes Wilda (Ferusa), Piotr Skarga, Fryderyk Nausea (Blandicampianusa), Johanna Herold (Discipulusa), Wincenty Ferreriusz, Jakub de Voragine, Luis of Grenada called Granatensis, Johannes Hoffmeister, Johanna Eck (Eckiusa), Saint Bernard of Clairvaux, Peter Comestor, Saint Bonaventure, Gabriel Biela, Marcin Białobrzeski, Saint Beda, Stanisław Karnkowski, Saint Bernardine of Siena, Dionysius the Great, Hugon de Prato Florido, Nicholas of Błonia.

Dominican confessors, when getting ready for the award of the Sacrament of the Penance, read the manuals for confessors and works on moral theology inter alia by Gregory the Great, Angel de
\end{abstract}


Clavasio, Andreas de Escobar, Martinus Azpilcuety, Thomas Stapleton, Saint Rajmund of Peñafort, Peter of Soto, Antonii Pierozzi (Antonii de Foligno) and Jan Gerson.

In Friars Preachers Monasteries the Bible and Concordance were also diligently studied. The list of readings covered the writings of Dominican Fathers, Doctors and Apologists for the Church: Saint Augustyn of Hippony, Saint Thomas of Aquin, Saint Gregory of Nazianzus, Saint Ambrose, Lactantius, Saint Cyprian, Saint Isidore of Seville, Saint John Chrysostom, Saint Hieronymus, Saint John Damascene, Pope Saint Eusebius, Saint Gregory the Great, Saint Atanazy, Saint Basil the Great, Saint Cyril of Alexandria.

In the seclusion offered by monasteries, Dominicans also practised asceticism and contemplated. Spiritual exercises in the convents under consideration were supported by the works of Denis the Carthusian, Hendrik Herp, Thomas a Kempis, Alain de la Roche (Alanusa de Rupe), Johannes Wild (Ferusa), Humbert de Romanis, Thomas Stapleton, Diego Estella, Luis of Granada.

The monks also read the hagiographic works by: Wincenty of Kielcza Vita sancti Stanislai Cracoviensis episcopi (Vita maior) or Vita sancti Stanislai episcopi Cracoviensis (Vita minor), Jacobus de Voragine: Legenda aurea Sanctorum, sive Lombardica Historia, and Peter Kanijs Notae de Sanctis, Piotr Skarga Żywoty Świętych [Eng.: Lives of Saints], Antonii Grodzicki and Seweryn Lubomlczyk, Life of Saint Jacek Odrowąż, Gregory of Tours Vita Patrum, Bartłomiej Paweł Szotarewicz Byssus et Purpura Seu Vita et Martyrium D. Stanislai Episcopi Cracoviensis.

Pope Gregory IX made Dominicans inquisitors who had to be perfect theologians to challenge infidels and heretics. Therefore they studied speculative and dogmatic theology and related works as well as polemical writings by: first of all Saint Thomas of Aquin, Piotr Lombard, Thomas de Vio Cajetan, Stanisław Hozjusz, Franciszek Kostera, Johann Eck, Walenty Poznański (Wróbel), Robert Bellarmin, Wojciech Nowopolski, Marcin Białobrzeski, Stanisław Orzechowski, Jakub Wujek. 